\title{
Can serum procalcitonin levels be useful in predicting spontaneous ureteral stone passage?
}

Nusret Can Cilesiz ${ }^{1 *}$, Arif Ozkan ${ }^{1}$, Arif Kalkanli ${ }^{1}$ Ali Eroglu ${ }^{2}$, Cem Tuğrul Gezmis ${ }^{3}$, Berkan Simsek ${ }^{4}$ and Burak Arslan ${ }^{1}$

\begin{abstract}
Background: Medical expulsive therapy (MET) is recommended for ureteral stones when there is no indication for interventional treatment. Spontaneous passage (SP) may not always be perceived in patients undergoing MET. We aimed to demonstrate the effects of inflammatory factors on spontaneous ureteral stone passage in patients undergoing MET.
\end{abstract}

Methods: Our study was conducted between August and November, 2016, in healthy volunteers and patients with a single distal ureteral stone between 5 and $10 \mathrm{~mm}$ in diameter and no indications for interventional therapy. Blood and urine samples from all patients and healthy volunteers were tested. The patients were followed up every 2 weeks for 1 month unless emergency situations appeared. Patients with stone-free status at follow-up were concluded to have achieved complete stone passage [SP(+)], and failure [SP(-)] was concluded if the patient had not passed the stone by the end of the study. Blood samples of the patients and the control group were analyzed, recording WBC (white blood cell), CRP (c-reactive protein), SED (sedimentation), MPV (mean platelet volume), NLR (neutrophil-tolymphocyte ratio), and serum procalcitonin levels. Abnormalities in urine samples were recorded. All patients received diclofenac sodium $75 \mathrm{mg} /$ day, tamsulosin $0.4 \mathrm{mg} /$ day, and at least $3 \mathrm{l} /$ day fluid intake. Patients were followed for a month with kidney, ureter, bladder (KUB) plain films, ultrasonography (USG), and unenhanced abdominal CT scans while undergoing MET. Comparative statistical analyses were performed between the SP(+) and SP(-) groups.

Results: The procalcitonin levels of the SP(-) group were significantly higher $(207 \pm 145.1 \mathrm{pg} / \mathrm{ml})$ than in the SP(+) group $(132.7 \pm 28.1 \mathrm{pg} / \mathrm{ml})(p=0.000)$. The leucocyturia rate of the SP(-) group was significantly higher than in the $\mathrm{SP}(+)$ group $(p=0.004)$. Based on the ROC curve analysis, $160 \mathrm{pg} / \mathrm{ml}(86.7 \%$ sensitivity, $70.8 \%$ specificity, $p<0.001$; AUC: 0.788 95\% Cl (0.658-0.917) was identified as the optimal cut-off value for procalcitonin. In logistic regression analysis, a significant efficacy of procalcitonin and leucocyturia was observed in the univariate analysis on spontaneous passage. In the multivariate analysis, significant independent activity was observed with procalcitonin. $(p<0.05)$.

Conclusion: Our findings suggest that high procalcitonin levels and the presence of leucocyturia have a strong negative effect on SP of ureteral stones between 5 and $10 \mathrm{~mm}$ in diameter. This relationship can be explained by stone impaction, possibly caused by increased mucosal inflammation.

Keywords: Ureteral stone, Spontaneous stone passage, Medical expulsive therapy, Serum procalcitonin, Leucocyturia

\footnotetext{
*Correspondence: nusretcancilesiz@gmail.com

'Department of Urology, GOP Taksim Education Training and Research

Hospital, Karayolları Str. No:621 Gaziosmanpasa, İstanbul, Turkey

Full list of author information is available at the end of the article
}

(c) The Author(s). 2020 Open Access This article is licensed under a Creative Commons Attribution 4.0 International License, which permits use, sharing, adaptation, distribution and reproduction in any medium or format, as long as you give appropriate credit to the original author(s) and the source, provide a link to the Creative Commons licence, and indicate if changes were made. The images or other third party material in this article are included in the article's Creative Commons licence, unless indicated otherwise in a credit line to the material. If material is not included in the article's Creative Commons licence and your intended use is not permitted by statutory regulation or exceeds the permitted use, you will need to obtain permission directly from the copyright holder. To view a copy of this licence, visit http://creativecommons.org/licenses/by/4.0/. The Creative Commons Public Domain Dedication waiver (http://creativecommons.org/publicdomain/zero/1.0/) applies to the data made available in this article, unless otherwise stated in a credit line to the data. 


\section{Background}

Urinary tract stones' localization is usually on the kidney, while ureteral stones make up $20 \%$ of all urinary system stones [1]. Patients with a ureteral stone usually present with complaints such as flank pain, nauseavomiting, and lower urinary tract symptoms [1, 2]. The most important parameter in determining the treatment to be applied is the size of the ureteral stones. Ureteral stones classified as non-complicated and smaller than $10 \mathrm{~mm}$ in diameter may be followed up for a month due to the possibility of spontaneous passage (SP).

Medical expulsive therapy (MET) is a non-invasive treatment modality that is especially recommended for ureteral stones $>5 \mathrm{~mm}$. MET consists of high fluid intake and medical agents such as anti-inflammatory drugs, alpha-blockers, calcium channel blockers, corticosteroids or phosphodiesterase inhibitors. It has been proven elsewhere that the likelihood and speed of spontaneous passage are increased with MET [1, 3]. Furthermore, MET decreases hospital visits, costs, and the requirement of interventional treatment [4-7].

Ureteral stones can cause inflammation in the ureteral wall, and this mucosal inflammation was found to be related to the impaction of the stone. In studies using serum inflammation markers to predict the impaction of ureteral stones, serum white blood cell (WBC), neutrophil count, c-reactive protein (CRP), and neutrophillymphocyte ratio (NLR) values were found to be related to the spontaneous passage of ureteral stones [8-11].

Procalcitonin is a polypeptide consisting of 116 amino acids, with a molecular weight of approximately 13 kilodaltons. Ghillani et al., 1989, first described this hormone as the precursor of calcitonin, which is made up of 32 amino acids [12]. In sepsis and inflammation, serum procalcitonin levels have been shown to increase following release of endotoxins and immunomodulators [13]. Furthermore, it has been reported that the elevation of procalcitonin may be used to indicate a relapse of chronic prostatitis, the rate of infection in obstructed ureteral stones, and the severity of inflammation in cholecystitis [14-16].

Despite MET, the spontaneous passage of ureteral stones smaller than $10 \mathrm{~mm}$ may not be observed in clinical practice. In recent years, many studies have investigated the reasons behind this circumstance [10, 11]. In light of these studies, we aimed to investigate the effect of serum procalcitonin and other inflammation markers at the time of diagnosis, for patients with ureteral stones sized 5-10 $\mathrm{mm}$.

\section{Methods}

This prospective observational study was conducted between August and November of 2016, after receiving institutional review board approval. The patients gave informed consent for participation at the beginning of the study.

Patients aged 20 to 60 years with renal colic and having a single distal ureteral stone $5-10 \mathrm{~mm}$ in diameter, detected by an unenhanced CT scan, were included in this study. Exclusion criteria from the study were the patients with severe hydronephrosis, symptomatic urinary system infection, findings of acute renal failure, congenital ureteral anomaly, a history of ureteral stenosis or reconstructive ureteral surgery, and those who had received anti-inflammatory or anti-microbial drugs for the ureteral stone. Patients with active infective disease, chronic inflammatory disease (e.g., ulcerative colitis, rheumatoid arthritis, ankylosing spondylitis), active neoplasia, thyroid disease with or without thyroid surgery, immunosuppression or immunosuppressive treatment were also excluded from the study. The control group included 33 healthy volunteers of the same age range and socio-demographic characteristics, no history of stone disease and no active or chronic disease.

The patients' characteristics including age, gender, BMI (body mass index), smoking history, chronic illnesses, drug allergies, previous stone interventions (nephropyelolithotomy, percutaneous surgery, URS-L or ESWL) were all recorded. Unenhanced abdominal CT scans were used to determine the stone size (dimension at its greatest diameter), area (width $\mathrm{x}$ length $\times 0.8$ ), laterality (left/right), and the degree of hydronephrosis.

Complete blood cell count, C-reactive protein (CRP), sedimentation, serum procalcitonin, urinalysis and urine culture were performed for both groups. In the complete blood cell count, values for white blood cells (WBC), neutrophil/lymphocyte ratio (NLR), mean platelet volume (MPV), and red cell distribution width (RDW) were noted. In the urinalysis, the presence or absence of leucocyturia and bacteriuria were noted. The BioVendor (Czechia) Human Procalcitonin ELISA (RD191006200R) kit was used to measure the procalcitonin level. Serums were analyzed using the Biotek Elx-800 microplate reader and Biotek Gen5 software.

All patients received diclofenac sodium $75 \mathrm{mg} /$ day, tamsulosin $0.4 \mathrm{mg} /$ day and at least $3 \mathrm{l} /$ day fluid intake. The patients were followed up with kidney, ureter, bladder (KUB) plain films, ultrasonography (USG) and unenhanced abdominal CT scan every 2 weeks for 1 month unless emergency situations appeared. Patients with stone-free status at follow-up were concluded to have achieved complete stone passage $[\mathrm{SP}(+)]$, and failure $[\mathrm{SP}(-)]$ was concluded if the patient had not passed the stone by the end of the study.

\section{Statistical analyses}

Mean, standard deviation, median, lowest and highest scores, frequency and ratio values were used for the 
descriptive statistics of the data. Distribution of variables was obtained using the Kolmogorov Smirnov test. The Mann-Whitney $U$ test was utilized for analyses of the independent quantitative data. For the analyses of independent categorical data, the chi square test was preferred, and when it was not applicable, Fischer's exact test was substituted. Impact level and cut-off values were determined using the ROC curve. The effect level was investigated by univariate and multivariate logistic regression. All analyses were conducted with SPSS 22.0; the accepted level of statistical significance was $p<0.05$.

\section{Results}

According to the exclusion criteria, 11 patients were excluded from the study, and the data of the case $(n=54)$ and control $(n=33)$ groups were analyzed. None of the patients showed symptoms requiring intervention treatment, such as high fever, renal colic attacks that cannot be controlled with analgesics, progressive hydronephrosis or renal failure, during the follow-up period.

There were no significant differences between the case and the control groups in terms of bacteriuria ratio, WBC or CRP values. However, the leucocyturia ratio, RDW, NLR, sedimentation and procalcitonin values were significantly higher in the case group $(p<0.05)$ (Table 1$)$.

Based on the follow-up controls, 30 patients (55.5\%) passed the stone $[\mathrm{SP}(+)]$, whereas passage did not occur in 24 patients $(44.5 \%)$ [ $\mathrm{SP}(-)]$. Age, gender, BMI, smoking history, and previous stone-related intervention rates were similar in both groups except stone distributions $(p<0.05)$ (Table 2).

Table 1 Comparison of case and control groups's sosyodemographic characteristics and biochemichal inflammation markers

\begin{tabular}{llll}
\hline & Case Group & Control Group & $\mathrm{P}$ \\
\hline Age (years) & $37,1 \pm 10,2$ & $33,9 \pm 8,3$ & 0,159 \\
Gender & Male 38 (70,4\%) & Male 27 (81,8\%) & 0,233 \\
BMI (kg/m ${ }^{\mathbf{2}}$ ) & $26,5 \pm 4,1$ & $24,8 \pm 5,1$ & 0,245 \\
WBC (10 $\mathbf{3} / \mu \mathrm{L})$ & $8,8 \pm 2,3$ & $8,0 \pm 1,9$ & 0,553 \\
RDW (\%) & $15,5 \pm 1,9$ & $12,8 \pm 0,9$ & $\mathbf{0 , 0 0 0}$ \\
NLR (\%) & $2,8 \pm 1,7$ & $2,0 \pm 0,3$ & $\mathbf{0 , 0 0 9}$ \\
MPV (fL) & $8,6 \pm 1,0$ & $8,5 \pm 0,7$ & 0,451 \\
CRP (mg/L) & $10,4 \pm 12,6$ & $4,0 \pm 1,1$ & 0,088 \\
Sedimentation (mm/h) & $13,4 \pm 9,9$ & $4,2 \pm 1,3$ & $\mathbf{0 , 0 0 0}$ \\
Procalcitonin (pg/ml) & $165,7 \pm 104,7$ & $128,2 \pm 36,6$ & $\mathbf{0 , 0 0 4}$ \\
Bacteriuria (+) & $3,7 \%$ & $0 \%$ & 0,524 \\
Leucocyturia (+) & $37 \%$ & $0 \%$ & $\mathbf{0 , 0 0 0}$
\end{tabular}

$B M I$ Body mass index; WBC White blood cell; NLR Neutrophil-lymphocite ratio; $M P V$ Mean platelet volume; $C R P$ C-reactive protein
Table 2 Sosyodemographic characteristics and stone history of $\mathrm{SP}(-)$ and $\mathrm{SP}(+)$ groups

\begin{tabular}{|c|c|c|c|}
\hline & $\mathrm{SP}(-)$ & $\mathrm{SP}(+)$ & $\mathrm{p}$ \\
\hline Age (years) & $35,8 \pm 9,3$ & $38,0 \pm 10,9$ & 0,381 \\
\hline Gender (F/M) \% & $41,7 / 58,3$ & $20 / 80$ & 0,083 \\
\hline BMI $\left(\mathrm{kg} / \mathrm{m}^{2}\right)$ & $26,4 \pm 4,7$ & $26,5 \pm 3,6$ & 0,781 \\
\hline Smoking history & $\% 50$ & $\% 53,3$ & 0,808 \\
\hline Previous ESWL & $\% 12,5$ & $\% 16,7$ & 0,668 \\
\hline Previous Stone surgery & $\% 8,3$ & $\% 6,7$ & 0,816 \\
\hline Stone burden $\left(\mathrm{mm}^{2}\right)$ & $30 \pm 8.2$ & $29.1 \pm 10.3$ & 0,310 \\
\hline Stone distrubition (R/L) & $16 / 14$ & 13/11 & 0,745 \\
\hline
\end{tabular}

Between the $\mathrm{SP}(-)$ and $\mathrm{SP}(+)$ groups, bacteriuria ratios, WBC, RDW, NLR, MPV, CRP, and sedimentation values were not significantly different $(p>0.05)$.

Compared to the SP $(+)$ group, mean serum procalcitonin levels $(207 \pm 145.1$ vs $132.7 \pm 28.1 \mathrm{pg} / \mathrm{ml}, p=0.000)$ and the leucocyturia ratio (58.3 vs. $20 \%, p=0.004$ ) were significantly higher in the SP (-) group (Table 3). Based on the ROC curve analysis, $160 \mathrm{pg} / \mathrm{ml}(86.7 \%$ sensitivity, $70.8 \%$ specificity, $p<0.001$; AUC: 0.788 95\% CI $(0.658$ 0.917 ) was identified as the optimal cut-off value for procalcitonin (Fig. 1). In logistic regression analysis, a significant efficacy of procalcitonin and leucocyturia was observed in the univariate analysis of spontaneous passage. In the multivariate analysis, significant independent activity was observed with procalcitonin. (Table 4$)(p<0.05)$.

\section{Discussion}

Observation with MET protocol, ESWL and URS-L are the treatment options for the ureteral stones and could be preferred based on the patient's clinical condition and size of the stone. Treatment success for ESWL and URS-L depends on localization and size of the stone and is reported to be $68-90 \%$ and $80-97 \%$ respectively [1]. Even though high success rates occur from these treatment modalities, high costs and complication risks must

Table 3 Effect of biochemichal inflammation markers for spontaneous ureteral stone passage

\begin{tabular}{llll}
\hline & $\mathrm{SP}(-)$ & $\mathrm{SP}(+)$ & $\mathrm{P}$ \\
\hline WBC (10 $\mathbf{3} / \boldsymbol{\mu L})$ & $8,4+2,3$ & $9,1+2,4$ & 0,261 \\
RDW (\%) & $15,5+2,4$ & $15,4+1,5$ & 0,657 \\
NLR (\%) & $2,8+1,7$ & $2,9+1,7$ & 0,821 \\
MPV (fL) & $8,7+0,6$ & $8,5+1,3$ & 0,721 \\
CRP (mg/L) & $9,0+8,2$ & $11,5+15,4$ & 0,875 \\
Sedimentation (mm/h) & $11,8+7$ & $14,7+11,7$ & 0,558 \\
Procalcitonin (pg/ml) & $207+145,1$ & $132,7+28,1$ & $\mathbf{0 , 0 0 0}$ \\
Leucocyturia (+)(\%) & $58,3 \%$ & $20 \%$ & $\mathbf{0 , 0 0 4}$ \\
\hline
\end{tabular}

WBC White blood cell; NLR Neutrophil-lymphocite ratio; MPV Mean platelet volume; $C R P$ C-reactive protein 


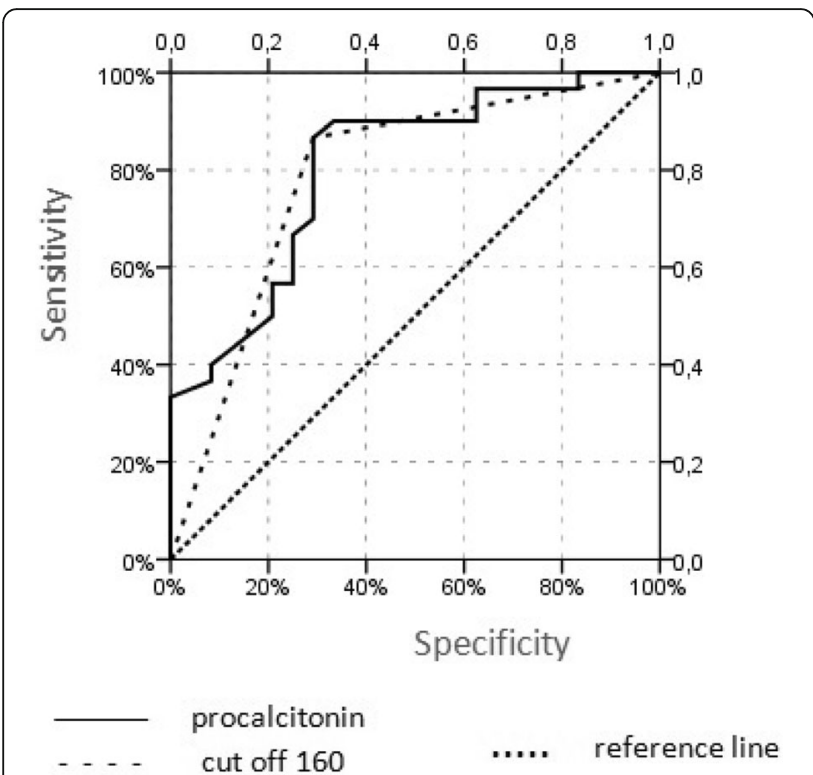

Fig. 1 ROC curve for cutoff value of $160 \mathrm{pg} / \mathrm{ml}$ of procalcitonin on prediction of spontaneous ureteral stone passage

be weighed as to their primary disadvantages [17, 18]. Moreover, the financial burden of having additional laboratory tests is another controversy about whether a ureteral stone can be spontaneously evacuated or not [18]. Similarly, complications such as recurrent renal colic attacks, urosepsis, and urinary tract infections may occur; observation or MET is therefore to be preferred for those patients. During the observation, ureteral stone impaction may also be observed due to ureteral mucosal inflammation, resulting in a more difficult and complicated treatment process of the ureteral stone [11]. For these reasons, accurate prediction of spontaneous passage has taken on greater importance in recent years, and several studies have been conducted in this area.

Recent studies have determined the likelihood of spontaneous passage in ureteral stones $<5 \mathrm{~mm}$ to be $71-100 \%$, and $25-46 \%$ in stones measuring $5-10 \mathrm{~mm}$. Also, for ureteral stones $<4 \mathrm{~mm}$, the possibility of spontaneous passage within 40 days was reported to be $95 \%$ [1, 19]. One study classified stones into three groups based on size and reported spontaneous passage rates of 89.9, 63.4 and $9.1 \%$ for $<5 \mathrm{~mm}, 5-10 \mathrm{~mm}$ and $>10 \mathrm{~mm}$ ureteral stones, respectively [20]. In another study, which compared observation and MET for $5-10 \mathrm{~mm}$ ureteral stones, SP ratios were reported to be 50 and $81.8 \%$ respectively [21]. In our study, when medical expulsive therapy was conducted for the $5-10 \mathrm{~mm}$ ureteral stones, the SP rate was calculated to be $55.5 \%$.

Another important factor affecting the possibility of SP in ureteral stones is localization. Studies indicate that as the stone approaches to distal, both the SP ratio and the greatest benefit from MET increase [22-24]. Although

Table 4 Logistic regression analysis for spontaneous passage in 5-10 mm distal ureteral stones

\begin{tabular}{|c|c|c|c|c|c|c|}
\hline & \multicolumn{3}{|c|}{ Univariate analysis } & \multicolumn{3}{|c|}{ Multivariate analysis } \\
\hline & OR & 95\% Confidence Interval & $p$ & OR & 95\% Confidence Interval & $\mathrm{p}$ \\
\hline Age (years) & 1,02 & $0,97-1,08$ & 0,447 & & & \\
\hline Gender & 2,86 & $0,85-9,56$ & 0,088 & & & \\
\hline BMI & 1,00 & $0,88-1,15$ & 0,962 & & & \\
\hline Primary/secondary & 1,27 & $0,43-3,82$ & 0,665 & & & \\
\hline History of SWL & 0,96 & $0,32-2,93$ & 0,950 & & & \\
\hline History of stone passage & 1,40 & $0,30-6,56$ & 0,669 & & & \\
\hline History of stone surgery & 0,79 & $0,10-6,03$ & 0,817 & & & \\
\hline Smoking history & 1,14 & $0,39-3,35$ & 0,808 & & & \\
\hline Hydronephrosis & 0,58 & $0,19-1,72$ & 0,326 & & & \\
\hline Stone burden & 0,99 & $0,95-1,04$ & 0,732 & & & \\
\hline WBC & 1,14 & $0,89-1,46$ & 0,287 & & & \\
\hline RDW & 0,97 & $0,73-1,28$ & 0,807 & & & \\
\hline NLR & 1,03 & $0,74-1,43$ & 0,855 & & & \\
\hline MPV & 0,84 & $0,47-1,48$ & 0,547 & & & \\
\hline CRP & 1,02 & $0,97-1,07$ & 0,470 & & & \\
\hline Sedimentation & 1,03 & $0,97-1,10$ & 0,307 & & & \\
\hline Procalcitonin & 0,96 & $0,94-0,99$ & 0,002 & 0,94 & $0,89-0,98$ & 0,005 \\
\hline Leucocyturia & 0,18 & $0,05-0,60$ & 0,005 & & & \\
\hline
\end{tabular}


MET was employed in our study, the SP rate was lower than in other studies. AUA panels showed superior SFR for patients treated with MET (77.3\%) compared with placebo $(54.4 \%)$ on distal ureteral stones $<10 \mathrm{~mm}$ [22]. We believe that the lower rate of SFR (55.5\%) in our study was due to the $5-10 \mathrm{~mm}$ stone size in the patients in our research.

Lifestyle factors, such as smoking habits and sexual intercourse, have also been investigated in recent years as potential factors of spontaneous passage. Fazlıoğlu et al. reported similar SP ratios in $<4 \mathrm{~mm}$ distal ureter stones for smokers and non-smokers, but for $\geq 4 \mathrm{~mm}$ distal ureter stones, the SP ratio was reported to be lower in smokers [25]. In another study, Bayraktar et al. investigated three groups of patients with $5-10 \mathrm{~mm}$ distal ureteral stones receiving different treatments. Group 1 received tamsulosin $0.4 \mathrm{mg} /$ day, Group 2 was asked to have intercourse three times per week, and Group 3 received medical treatment. The authors reported that, based on their results, having sexual intercourse three times a week could be as beneficial as tamsulosin treatment [26]. We also compared SP levels in terms of BMI and smoking habits, but the differences were not significant $(p>0.05)$.

In recent years, the effect of some biochemical factors on the SP ratio has been reported. Ahmed et al. reported that patients with small stones, distal localization, high serum WBC level, low perinephric fat thickness, and lack of tissue-rim sign had increased SP ratios [27]. Similarly, another study reported significant correlations between the increase of WBC and neutrophil levels and the SP ratio, in $<10 \mathrm{~mm}$ ureteral stones $(p<0.001)$ [11]. According to the authors, this correlation was associated with increased ureteral peristalsis, caused by inflammation in the ureteral wall. By contrast, Aldaqodossi et al. reported that an increase in ureteral inflammation could decrease the SP ratio [8]. In this study, the authors reported that the $\mathrm{SP}(-)$ group was significantly higher than the $\mathrm{SP}(+)$ group for initial CRP values $(p=0.001)$. Furthermore, based on ROC curve analysis, it was found that sensitivity and specificity of the $21.9 \mathrm{mg} / \mathrm{dl}$ cut-off value for CRP, were 78.6 and $89.3 \%$ respectively [8]. In our study, the mean serum WBC value was higher in the $\mathrm{SP}(+)$ group, when compared to the $\mathrm{SP}(-)$ group $(9.1 \pm$ 2.4 vs. $8.4 \pm 2.3$ ), although this difference is not statistically significant. Similarly, mean CRP values were higher in the $\mathrm{SP}(+)$ group $(11.5 \pm 15.4)$ than in the $\mathrm{SP}(-)$ group $(9.0 \pm 8.2)$, and again, there is no statistically significant difference.

To our knowledge, the available literature does not include a study investigating the effect of serum procalcitonin on SP. However, procalcitonin has been reported to be valuable in showing a correlation between urinary tract infection and impacted ureteral stones. Papagiannopoulos et al. reported that procalcitonin $>100 \mathrm{pg} / \mathrm{ml}$ was detected in $18 \%$ of patients treated with MET, $45 \%$ of whom had undergone URS-L or ureteral stenting [16]. In our study, the mean serum procalcitonin level of the $\mathrm{SP}(-)$ group $(207.0 \pm 145.1 \mathrm{pg} / \mathrm{ml})$ was significantly higher than in the $\mathrm{SP}(+)$ group $(132.7 \pm 28.1$ $\mathrm{pg} / \mathrm{ml})(p=0.000)$. Furthermore, leucocyturia rates of the $\mathrm{SP}(-)$ group were significantly higher than in the $\mathrm{SP}(+)$ group (58.3\% vs. $20 \%)(p=0.004)$. This finding could better explain the relationship between high serum procalcitonin and mucosal inflammation. It has been reported in previous studies that leucocyturia did not effect on spontaneous passage; this finding should be re-evaluated through studies with larger sample sizes $[9,27]$.

The fact that procalcitonin is significant even in multivariant analysis increases the possibility of using this marker in daily practice in the future. Of course, the accuracy of this information should be supported by a larger series.

Based on these results, it could be argued that procalcitonin plays a role in predicting SP, but this hypothesis needs to be supported with studies having higher sample sizes. Also, measuring the procalcitonin level again at the end of the study could increase the strength of the study. Our sample size was not large enough for subgroup analysis, a limitation of our study. Particularly, evaluating the serum procalcitonin and leucocyturia through subgroup analysis may provide a more objective argument for our hypothesis.

\section{Conclusion}

This study reports that distal ureteral stones sized 5$10 \mathrm{~mm}$ presenting with high procalcitonin levels and leucocyturia may have a negative effect on spontaneous passage. This relationship can be explained by stone impaction, possibly caused by increased mucosal inflammation.

\section{Abbreviations \\ MET: Medical expulsive therapy; SP: Spontaneous passage; KUB: Kidney, ureter, bladder plain films; USG: Ultrasonography; CT: Computerized tomography; URS-L: Ureterorenoscopic lithotripsy; ESWL: Extracorporeal shock wave lithotripsy; VAS: Visual Analogue Scale; BMI: Body mass index; AUA: American Urological Association}

\section{Acknowledgements}

Not applicable.

\section{Authors' contributions}

NCC conceived the idea for the study, made the protocol and wrote the manuscript with NCC. NCC,CTG,AE performed the data collection, conducted the analyses and wrote the manuscript with BA. AK, AO and BS made the protocol and assisted with the data collection. AO, NCC, BS and AK had access to all of the research data. BA revised necessary pathology. NCC, AK, $A O$ and $B A$ assisted with protocol development. NCC, AO, AK, CTG, AE, BS and $\mathrm{BA}$ contributed to the interpretation of the data and critically revised earlier draft versions. All authors read and approved the final manuscript. 


\section{Funding}

No funding.

\section{Availability of data and materials}

All data generated or analysed during this study are included in this published article and its supplementary information files. If someone wants to access the data of the study, they can contact the corresponding author (nusretcancilesiz@gmail.com).

\section{Ethics approval and consent to participate}

Written ethics committee approval numbered 2016-5 was obtained from the ethics committee of GOP Taksim Education and Research Hospital for this study with a Helsinki declaration. Written informed consent for the current study was received from all patients and healthy volunteers.

\section{Consent for publication}

Not applicable.

\section{Competing interests}

All authors declares that they have no conflict of interests.

\section{Author details}

'Department of Urology, GOP Taksim Education Training and Research Hospital, Karayolları Str. No:621 Gaziosmanpasa, Istanbul, Turkey. ${ }^{2}$ Department of Urology, Yeniyüzyıl University Medicine Faculty, Gaziosmanpaşa Hospital, Istanbul, Turkey. ${ }^{3}$ Bitlis State Hospital, Bitlis, Turkey 410 Sancaktepe State Hospital, Istanbul, Turkey. ${ }^{4}$ Department of Urology, Sancaktepe State Hospital, Istanbul, Turkey.

Received: 4 May 2019 Accepted: 2 April 2020

Published online: 19 April 2020

\section{References}

1. Türk C, Petřík A, Sarica K, Seitz C, Skolarikos A, Straub M, et al. EAU guidelines on diagnosis and conservative Management of Urolithiasis. Eur Urol. 2016:69(3):468-74.

2. Pak CY. Kidney stones. Lancet. 1998;351(9118):1797-1801. Review.

3. Ordon M, Andonian S, Blew B, Schuler T, Chew B. Pace KT CUA, guideline: management of ureteral calculi. Can Urol Assoc J. 2015;9(11-12):E837-51.

4. Singh A, Alter HJ, Littlepage A. A systematic review of medical therapy to facilitate passage of ureteral calculi. Ann Emerg Med. 2017;50:552-63.

5. Loftus C, Nyame Y, Hinck B, Greene D, Chaparala H, Alazem K, et al. Medical expulsive therapy is underused for the management of renal colic in the emergency setting. J Urol. 2016;195(4 Pt 1):987-91.

6. Brede C, Hollingsworth JM, Faerber GJ, Taylor JS, Wolf JS Jr. Medical expulsive therapy for ureteral calculi in the real world: targeted education increases use and improves patient outcome. J Urol. 2010;183:585-9.

7. Furyk JS, Chu K, Banks C, Greenslade J, Keijzers G, Thom O et al Distal Ureteric Stones and Tamsulosin: A Double-Blind, Placebo-Controlled, Randomized, Multicenter Trial. Ann Emerg Med. 2016;67(1):86-95.e2.

8. Aldaqadossi HA. Stone expulsion rate of small distal ureteric calculi could be predicted with plasma C-reactive protein. Urolithiasis. 2013;41(3):235-9.

9. Lee KS, Ha JS, Koo KC. Significance of neutrophil-to-lymphocyte ratio as a novel Indicator of spontaneous ureter stone passage. Yonsei Med J. 2017: 58(5):988-93.

10. Özcan C, Aydoğdu O, Senocak C, Damar E, Eraslan A, Oztuna D, et al. Predictive factors for spontaneous stone passage and the potential role of serum C-reactive protein in patients with 4 to $10 \mathrm{~mm}$ distal ureteral stones: a prospective clinical study. J Urol. 2015;194(4):1009-13.

11. Sfoungaristos S, Kavouras A, Katafigiotis I, Perimenis P. Role of white blood cell and neutrophil counts in predicting spontaneous stone passage in patients with renal colic. BJU Int. 2012;110(8 Pt B):E339-45.

12. Aouifi A, Piriou V, Blanc P, et al. Effect of cardiopulmonary bypass on serum procalcitonin and C-reactive protein concentrations. Br J Anaesth. 1999;83: 602-7.

13. Meisner M. Procalcitonin: a new innovative infection parameter. In: Meisner M, ed. Biochemistry. Stuttgart: Brahms Diagnostica; 2000: 15.

14. Çakıroğlu B, Eyyüpoğlu E, Balcı MBC, Hazar Ai, Uyanık BS, Doğan AN. The evaluation of the procalcitonin levels in chronic prostatitis patients. Nobel Med. 2016;12(2):60-5.
15. Yuzbasioglu Y, Duymaz H, Tanrikulu CS, Halhalli HC, Koc MO, Tandoğan M et al. Role of Procalcitonin in evaluation of the severity of acute Cholecystitis. Eurasian J Med. 2016;48(3):162-6.

16. Papagiannopoulos D, Whelan P, Ahmad W, Rybak J, Hota B, Deane L, et al. Procalcitonin is a strong predictor of urine culture results in patients with obstructing ureteral stones: a prospective, pilot study. Urol Ann. 2016;8(3): 277-80.

17. Skolarikos A, Alivizatos $G$, de la Rosette J. Extracorporeal shock wave lithotripsy 25 years later: complications and their prevention. Eur Urol. 2006: 50(5):981-90 discussion 990.

18. Perez Castro E, Osther PJ, Jinga V, Razvi H, Stravodimos KG, Parikh K, et al. CROES Ureteroscopy global study group. Differences in ureteroscopic stone treatment and outcomes for distal, mid-, proximal, or multiple ureteral locations: the clinical research Office of the Endourological Society ureteroscopy global study. Eur Urol. 2014:66(1):102-9.

19. Skolarikos A, Laguna MP, Alivizatos G, Kural AR, de la Rosette JJ. The role for active monitoring in urinary stones: a systematic review. J Endourol. 2010; 24(6):923-30.

20. Demehri S, Steigner ML, Sodickson AD, Houseman EA, Rybicki FJ, Silverman SG. CT-based determination of maximum ureteral stone area: a predictor of spontaneous passage. AJR Am J Roentgenol. 2012;198(3):603-8.

21. Chau LH, Tai DC, Fung BT, Li JC, Fan CW, Li MK. Medical expulsive therapy using alfuzosin for patient presenting with ureteral stone less than $10 \mathrm{~mm}$ : a prospective randomized controlled trial. Int J Urol. 2011;18(7):510-4.

22. Türk C, Knoll T, Seitz C, Skolarikos A, Chapple C, McClinton S;European Association of Urology. Medical expulsive therapy for Ureterolithiasis: the EAU recommendations in 2016. Eur Urol 2017;71(4):504-507. doi:https://doi. org/10.1016/j.eururo.2016.07.024. Epub 2016 Aug 6. PubMed PMID: 27506951.

23. Brubaker WD, Dallas KB, Elliott CS, Pao AC, Chertow GM, Leppert JT, Conti SL. Payer type, race/ethnicity, and the timing of surgical Management of Urinary Stone Disease. J Endourol. 2019;33(2):152-8.

24. Matlaga BR, Jansen JP, Meckley LM, Byrne TW, Lingeman JE. Treatment of ureteral and renal stones: a systematic review and meta-analysis of randomized, controlled trials. J Urol. 2012;188(1):130-7.

25. Fazlioglu A, Salman Y, Tandogdu Z, Kurtulus FO, Bas S, Cek M. The effect of smoking on spontaneous passage of distal ureteral stones. BMC Urol. 2014; 14:27.

26. Bayraktar Z, Albayrak S. Sexual intercourse as a new option in the medical expulsive therapy of distal ureteral stones in males: a prospective, randomized, controlled study. Int Urol Nephrol. 2017:49(11):1941-6.

27. Ahmed AF, Gabr AH, Emara AA, Ali M, Abdel-Aziz AS, Alshahrani S. Factors predicting the spontaneous passage of a ureteric calculus of $\leqslant 10 \mathrm{~mm}$. Arab J Urol. 2015:13(2):84-90.

\section{Publisher's Note}

Springer Nature remains neutral with regard to jurisdictional claims in published maps and institutional affiliations.

Ready to submit your research? Choose BMC and benefit from:

- fast, convenient online submission

- thorough peer review by experienced researchers in your field

- rapid publication on acceptance

- support for research data, including large and complex data types

- gold Open Access which fosters wider collaboration and increased citations

- maximum visibility for your research: over $100 \mathrm{M}$ website views per year

At BMC, research is always in progress.

Learn more biomedcentral.com/submissions 